\title{
TET3 Gene
}

National Cancer Institute

\section{Source}

National Cancer Institute. TET3 Gene. NCI Thesaurus. Code C162379.

This gene plays a role in epigenetic oxygenation of modified deoxycytosines in DNA strands. 